\title{
Krajowe i międzynarodowe standardy naprawy statków
}

\section{National and international standards for ship repair}

\section{Streszczenie}

W artykule przedstawiono ogólne wymagania dotyczące standardów napraw w odniesieniu do uszkodzonych jednostek pływających na skutek kolizji, zużycia korozyjnego itp., celem przywrócenia pierwotnego stanu konstrukcji. Z uwagi na zbieżność wymagań zawartych w przepisach Międzynarodowego Stowarzyszenia Towarzystw Klasyfikacyjnych (IACS) i Polskiego Rejestru Statków S.A., wymagania odnośnie do materiałów, spawania i standardu jakości napraw przedstawiono w oparciu o publikację informacyjną nr 16/l PRS S.A.

\section{Międzynarodowe Stowarzyszenie Towarzystw Klasyfikacyjnych (IACS)}

Międzynarodowe Stowarzyszenie Towarzystw Klasyfikacyjnych (IACS) jest organizacją składającą się z trzynastu morskich towarzystw klasyfikacyjnych $z$ siedzibą $w$ Londynie [7]. IACS jest organizacją pozarządową, lecz odgrywa znaczącą rolę w Międzynarodowej Organizacji Morskiej (IMO), która zapewnia pomoc techniczną i doradztwo oraz rozwija ujednolicone interpretacje międzynarodowych przepisów ustawowych, opracowywanych przez państwa członkowskie IMO.

IACS ma status doradcy przy Organizacji Morskiej i jest tylko organizacją pozarządową ze statusem obserwatora, który opracowuje i stosuje przepisy techniczne, będące odbiciem celów zawartych w ramach konwencji IMO. Związek pomiędzy międzynarodowymi przepisami morskimi, opracowanymi przez IMO i wymaganiami reguł klasyfikacyjnych statku dotyczących konstrukcji kadłuba i głównych systemów inżynierskich, jest skodyfikowany w Międzynarodowej Konwencji o Bezpieczeństwie Życia na Morzu (SOLAS).

Towarzystwa klasyfikacyjne promują „bezpieczeństwo morskie" i zajmują się głównie klasyfikacją jednostek pływających, mają swoje placówki

Dr inż. Ryszard Pakos - Zachodniopomorski Uniwersytet Technologiczny w Szczecinie. i przedstawicielstwa w najważniejszych portach na całym świecie, zatrudniając przy tym wysokiej klasy inspektorów i rzeczoznawców. Nadzór nad nowo budowaną jednostką sprawowanych jest dwuetapowy: zatwierdzenie dokumentacji i przegląd zasadniczy.

Jednostki pływające poddawane są przeglądom konwencyjnym oraz klasyfikacyjnym poprzez przeglądy roczne, pośrednie i w celu odnowienia klasy.

Międzynarodowe Stowarzyszenie Towarzystw Klasyfikacyjnych powstało 11 września 1968 r. w Hamburgu. Swoim zasięgiem i standardami klasyfikacyjnymi obejmuje ponad $90 \%$ światowego tonażu statków.

Do najważniejszych towarzystw klasyfikacyjnych należy zaliczyć: Lloyd's Register of Shipping LR; Bureau Veritas BV; Registro Italiano Navale RINA; American Burean of Shipping ABS; Det Norske Veritas DNV; Germanischer Lloyd GL; Nippon Kaiji Kyokai NKK; Rosyjski Morski Rejestr Nawigacyjny RS; Hellenic Register of Shipping HR; Polski Rejestr Statków PRS; China Classification Society CCS i Korean Register of Shipping KR.

Polski Rejestr Statków został przyjęty do Międzynarodowego Stowarzyszenia Towarzystw Klasyfikacyjnych (IACS) w 1970 r. Dzięki temu w 1971 r. PRS został wpisany do klauzuli ubezpieczeniowej Ubezpieczycieli Londyńskich, co oznaczało stosowanie wobec statków z klasą PRS oraz przewożonych na nich towarów najkorzystniejszych stawek ubezpieczeniowych. Członkostwo w IACS spowodowało włączenie 
PRS w prace naukowo-badawcze prowadzone przez instytucje stowarzyszone, dostęp do ich wyników oraz możliwość poznawania stosowanej na świecie metodologii postępowania nadzorczego. Pod koniec 2000 r. na skutek niespełnienia kryterium tonażu klasyfikowanej floty i ostrej walki konkurencyjnej na rynku międzynarodowym PRS został wykreślony z listy członków IACS, do której ponownie powrócił w czerwcu 2011 r., co zbiegło się z jubileuszem 75-lecia firmy.

\section{Typowe przyczyny napraw}

Najczęstszą przyczyną napraw jednostek pływających pływajacych są ich uszkodzenia na skutek kolizji bądź korozji spowodowanej agresywnym środowiskiem, w jakich eksploatowane sa statki morskie i śródlądowe. Ubytki korozyjne pociągają za sobą duże straty wynikające z konieczności $[5,6]$ :

- zwiększenia grubości elementów konstrukcyjnych na nowych statkach ponad wartości wymagane względami wytrzymałościowymi, co powoduje zmniejszenie nośności statku;

- wymiany elementów konstrukcyjnych o przekroczonej grubości - na jednostkach w eksploatacji.

Aktywność korozyjna wody morskiej zależy od stopnia jej zasolenia, składu chemicznego i temperatury [5].

Na rysunkach $1 \div 4$ przedstawiono przyczyny uszkodzeń jednostek pływających.

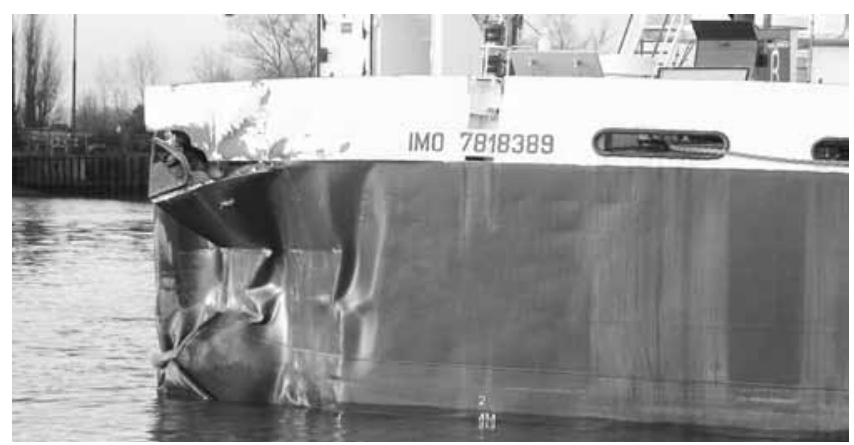

Rys. 1. Uszkodzenie rufy statku w wyniku kolizji

Fig. 1. Damage to the stern of the ship as a result of collision

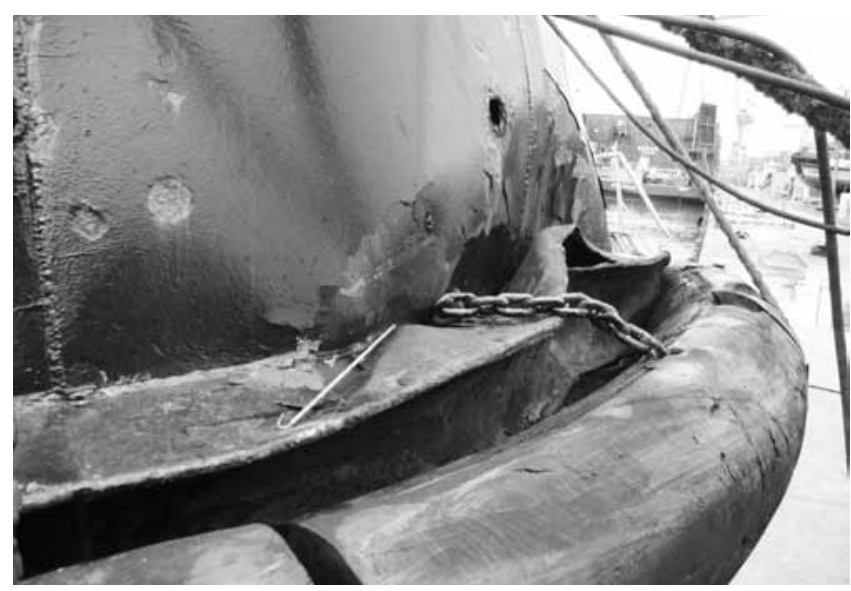

Rys. 2. Uszkodzenie dziobu (forpik i nadburcie)

Fig. 2. Damage to the bow (forepeak and bulwarks)

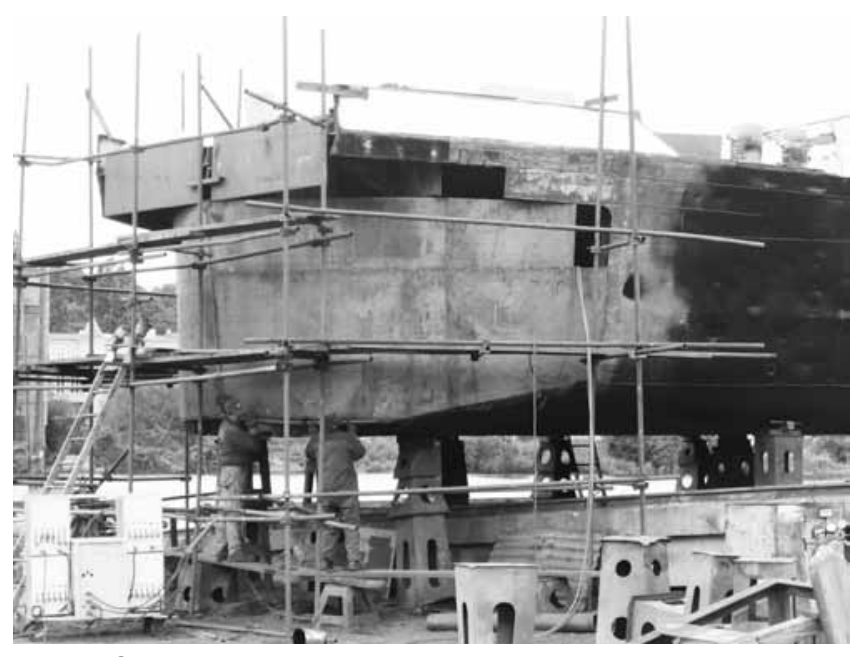

Rys. 3. Odbudowa (przebudowa) dziobu barki

Fig. 3. Reconstruction of barge bow

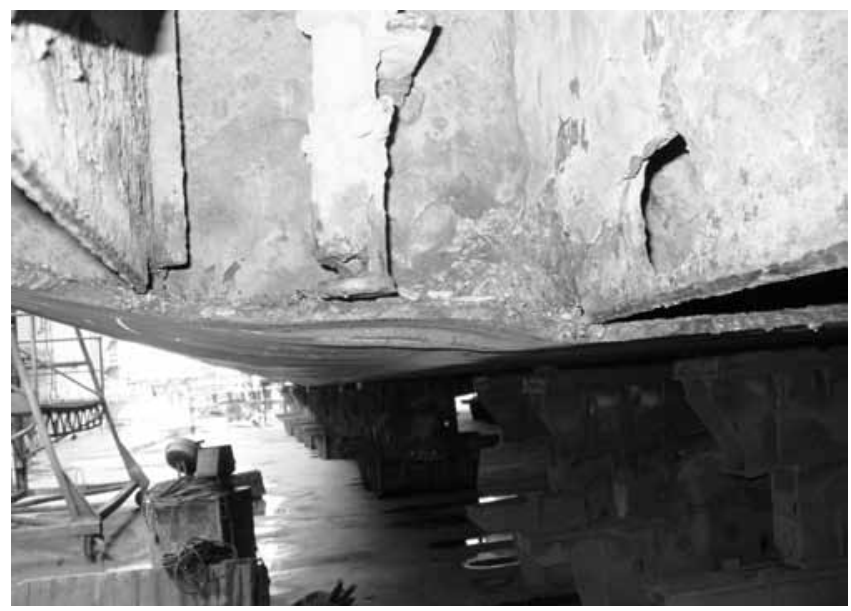

Rys. 4. Wymiana poszycia dennego. Naprawa usztywnień rampy rufowej

Fig. 4. Replacing the hull bottom. Repair of stiffening stern ramp

\section{Standardy napraw [1]}

Wytyczne zawarte w publikacji informacyjnej $\mathrm{nr}$ 16/I Polskiego Rejestru Statków są spójne i odpowiadają wymaganiom zawartym w materiałach IACS [2], stąd też standardy napraw statków przedstawiono w oparciu o materiały PRS S.A. Przywołana publikacja obejmuje typowe naprawy oraz zawiera wytyczne dotyczące standardów najważniejszych rodzajów tych napraw. Tam, gdzie nie podano dodatkowych wymagań, poziom wykonawstwa przedstawiony w publikacji może być taki sam, jak wymagany w stosunku do wiązarów i usztywnień konstrukcji oryginalnej. Dla krytycznych ze względu na wytrzymałość miejsc kadłuba i tam, gdzie występują wysokie obciążenia, wymagane są bardziej surowe standardy wykonawstwa, które powinny być w każdym przypadku uzgodnione z PRS. 


\section{Materiały}

Wymagania dotyczące materiałów stosowanych w naprawach są takie same, jak wymagania dotyczące materiałów dla nowych budów [3]. Powinny być one tej samej kategorii jak zatwierdzony materiał pierwotny. Alternatywnie mogą zostać zaakceptowane przez PRS materiały, spełniające uznane normy międzynarodowe lub krajowe, jeśli wymagania tych norm zapewniają równoważność w stosunku do wymagań dotyczących kategorii pierwotnej lub zostały uzgodnione z PRS. Ocena równoważności kategorii materiałów powinna obejmować co najmniej następujące aspekty: obróbka cieplna (stan dostawy), skład chemiczny, właściwości mechaniczne i tolerancje.

W tablicy I przedstawiono wymagania dotyczące oceny równoważności kategorii stali, natomiast $w$ tablicy II podano wytyczne doboru kategorii stali zgodnie z określonymi, uznanymi normami w porównaniu z kategoriami stali kadłubowych podanymi w przepisach PRS.

Przy doborze porównywalnych kategorii stali wg tej tablicy należy uwzględnić wymagania podane w tablicy I oraz wymagania dotyczące wymiarów wyrobu przedstawione w przepisach PRS.

Tablica I. Minimalny zakres i wymagania do oceny równoważności kategorii stali normalnych lub stali kadłubowych o zwykłej lub podwyższonej wytrzymałości [1]

Table I. Minimum range and requirements for assessing the equivalence of the category of normal steel or hull steel with normal or high strength [1]

\begin{tabular}{|c|c|c|}
\hline Właściwości & Wymagania & Uwagi \\
\hline \begin{tabular}{|l|} 
Skład \\
chemiczny
\end{tabular} & $\begin{array}{l}\text { Zawartość: } \\
\text { - C - równa lub niższa } \\
\text { - P i S - równa lub niższa } \\
\text { - Mn - w przybliżeniu taka sama, lecz nieprzekraczająca 1,6\% } \\
\text { - pierwiastki rozdrabniające ziarno - w tej samej ilości } \\
\text { Wymagane jest stosowanie odtleniania }\end{array}$ & Suma $\mathrm{Cu}, \mathrm{Ni}$, Cr i Mo nie powinna przekraczać $0,8 \%$ \\
\hline $\begin{array}{l}\text { Właściwości } \\
\text { mechaniczne }\end{array}$ & $\begin{array}{l}\text { - wytrzymałość na rozciąganie - równa lub wyższa } \\
\text { - granica plastyczności - równa lub wyższa } \\
\text { - wydłużenie po rozerwaniu - równe lub wyższe } \\
\text { - praca łamania - równa lub wyższa przy tej samej } \\
\text { lub niższej temperaturze }\end{array}$ & $\begin{array}{l}\text { Granica plastyczności nie powinna przekraczać } \\
\text { wymagań minimalnych zawartych w przepisach PRS } \\
\text { o więcej niż } 80 \mathrm{MPa}\end{array}$ \\
\hline Stan dostawy & Taki sam lub lepszy & $\begin{array}{l}\text { Obróbka cieplna w następującej kolejności: } \\
\text { - stan surowy (AR) } \\
\text { - walcowanie regulowane (CR) } \\
\text { - normalizowanie (N) } \\
\text { - walcowanie cieplno-mechaniczne (TM) }{ }^{11} \\
\text { - ulepszanie cieplne }(\mathrm{QT})^{1)} \\
\text { 1) Stale walcowane cieplno-mechanicznie i stale ulepsza- } \\
\text { ne cieplnie nie są odpowiednie do formowania na gorąco. }\end{array}$ \\
\hline Tolerancje & Takie same lub ostrzejsze & $\begin{array}{l}\text { Dopuszczalna tolerancja zmniejszenia grubości: } \\
\text { - płyty: } 0,3 \mathrm{~mm} \\
\text { - kształtowniki: zgodnie z uznanymi normami }\end{array}$ \\
\hline
\end{tabular}

Tablica II. Kategorie stali porównywalnych z kategoriami stali kadłubowych o normalnej i podwyższonej wytrzymałości [1]

Table II. Categories comparable with the categories of hull steel with normal and high strength [1]

\begin{tabular}{|c|c|c|c|c|c|c|c|c|c|c|}
\hline \multicolumn{7}{|c|}{ Kategorie stali wg przepisów PRS } & \multicolumn{4}{|c|}{ Porównywalne kategorie stali } \\
\hline \multirow{3}{*}{ Kategoria } & \multirow{3}{*}{$\begin{array}{c}\text { Granica pla- } \\
\text { styczności } \\
\mathrm{R}_{\mathrm{eH}}, \min ., \mathrm{MPa}\end{array}$} & \multirow{3}{*}{$\begin{array}{c}\text { Wytrzymałość } \\
\text { na rozciąganie } \\
\mathrm{R}_{\mathrm{m}}, \mathrm{MPa}\end{array}$} & \multirow{3}{*}{$\begin{array}{c}\text { Wydłużenie po } \\
\text { rozerwaniu } \\
A_{\text {min. }} \%\end{array}$} & \multicolumn{3}{|c|}{ Próba łamania } & \multirow{3}{*}{$\begin{array}{c}\text { ISO } \\
630-80 \\
4950 / 2 / 3 \\
1981\end{array}$} & EN & ASTM & JIS \\
\hline & & & & \multirow[t]{2}{*}{$\begin{array}{l}\text { Temp. } \\
{ }^{\circ} \mathrm{C}\end{array}$} & \multicolumn{2}{|c|}{$\begin{array}{l}\text { Praca łamania } \\
\text { (średnia war- } \\
\text { tość), J, min. }\end{array}$} & & \multirow[t]{2}{*}{$\begin{array}{l}\text { EN 10025-93 } \\
\text { EN 10113-93 }\end{array}$} & \multirow[t]{2}{*}{ A 131} & \multirow[t]{2}{*}{ G3106 } \\
\hline & & & & & $\mathrm{L}$ & $\mathrm{T}$ & & & & \\
\hline A & 235 & $400-520$ & 22 & +20 & & & $\mathrm{Fe} 360 \mathrm{~B}$ & S235JRG2 & A & SM41B \\
\hline $\mathrm{B}$ & & & & 0 & 27 & 20 & Fe 360C & S235J0 & B & SM41B \\
\hline $\mathrm{D}$ & & & & -20 & 27 & 20 & Fe 360D & S235J2G3 & $\mathrm{D}$ & (SM41C) \\
\hline $\mathrm{E}$ & & & & -40 & 27 & 20 & - & S275NL/ML & $\mathrm{E}$ & - \\
\hline $\mathrm{AH} 32$ & & & & 0 & & & - & - & $\mathrm{AH} 32$ & SM50B \\
\hline $\mathrm{DH} 32$ & 315 & $440-570$ & 22 & -20 & 31 & 22 & - & - & $\mathrm{DH} 32$ & (SM50C) \\
\hline EH3 2 & & & & -40 & & & - & - & EH32 & - \\
\hline $\mathrm{AH} 36$ & & & & 0 & & & Fe510C & S355NM & $\mathrm{AH} 36$ & SM53B \\
\hline $\mathrm{DH} 36$ & 355 & $490-630$ & 21 & -20 & 34 & 24 & Fe510D & S355NM & $\mathrm{DH} 36$ & (SM53C) \\
\hline $\mathrm{EH} 36$ & & & & -40 & & & E355E & S355NL/ML & EH36 & - \\
\hline $\mathrm{AH} 40$ & & & & 0 & & & E390CC & S420N/M & $\mathrm{AH} 40$ & (SM58) \\
\hline $\mathrm{DH} 40$ & 390 & $510-660$ & 20 & -20 & 41 & 27 & E390DD & S420N/M & $\mathrm{DH} 40$ & - \\
\hline $\mathrm{EH} 40$ & & & & -40 & & & E390E & S420NL/ML & $\mathrm{EH} 40$ & - \\
\hline
\end{tabular}




\section{Ogólne wymagania dotyczące spawania}

Warunki dotyczące podgrzewania wstępnego należy określać na podstawie składu chemicznego materiałów w zależności od procesu i technologii spawania oraz stopnia sztywności złącza.

Przy temperaturze otoczenia poniżej $0^{\circ} \mathrm{C}$ należy stosować podgrzewanie wstępne do temperatury min. $50^{\circ} \mathrm{C}$. W każdym przypadku należy zapewnić osuszenie strefy spawanej.

W tablicy III podano wytyczne dotyczące temperatury podgrzewania wstępnego dla stali o podwyższonej wytrzymałości. W przypadku stosowania procesu spawania automatycznego o zwiększonej ilości ciepła wprowadzanego, wartość temperatury można zmniejszyć o $50^{\circ} \mathrm{C}$. Natomiast przy ponownym spawaniu lub naprawie spoin podane wartości należy zwiększyć o $25^{\circ} \mathrm{C}$.

Spawanie poszycia kadłuba poniżej linii wodnej statków znajdujących się na wodzie dopuszczalne jest tylko dla stali o zwykłej i podwyższonej wytrzymałości dla granicy plastyczności nie większej niż $355 \mathrm{MPa}$ i tylko w przypadku napraw miejscowych. Technologia spawania dotycząca innych stali o podwyższonej wytrzymałości lub w przypadku poważniejszych napraw poniżej linii wodnej podlega osobnemu rozpatrzeniu i uzgodnieniu przez PRS.

Spawanie poszycia kadłuba poniżej linii wodnej należy przeprowadzić z zastosowaniem elektrod lub procesów niskowodorowych. Elektrody niskowodorowe otulone, stosowane do spawania ręcznego, należy odpowiednio wysuszyć przed spawaniem w celu zminimalizowania zawartości wodoru w stopiwie.

Tablica III. Temperatura podgrzewania wstępnego [1]

Table III. Temperature of preheating [1]

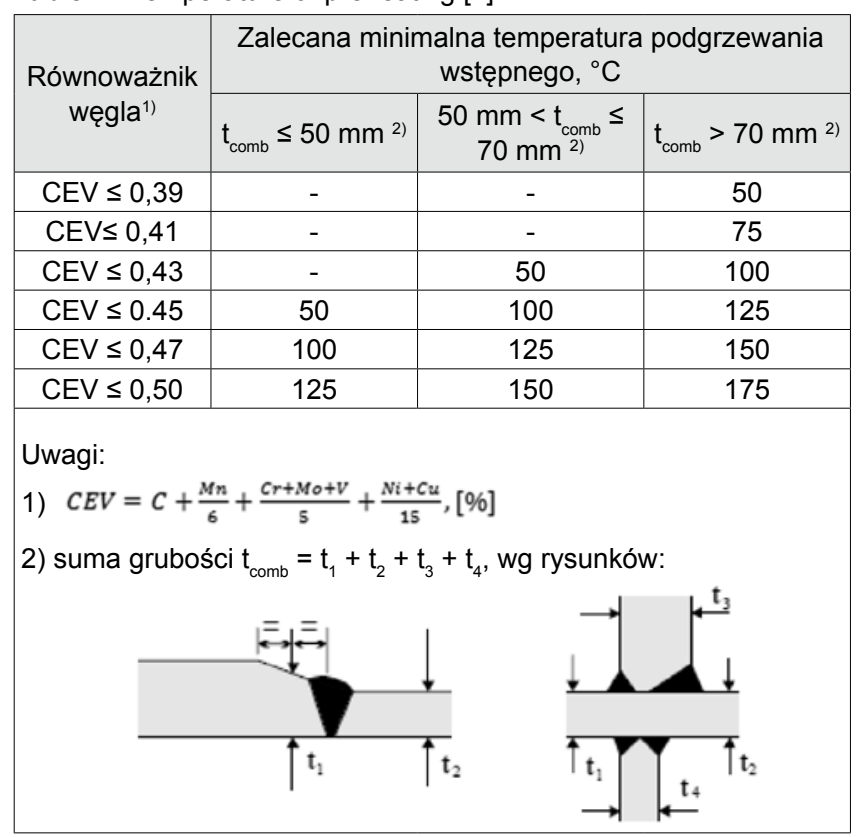

W celu osuszenia i zmniejszenia szybkości stygnięcia, konstrukcja powinna być przed spawaniem podgrzewana wstępnie palnikiem lub podobnym urządzeniem do temperatury min. $5^{\circ} \mathrm{C}$ lub podanej w technologii spawania.

\section{Standardy jakości napraw}

Zalecenia dotyczące wymiany płyt, elementów wewnętrznych, zakończenia nakładek, napawania wżerów korozyjnych oraz napraw pęknięć metodą spawania przedstawiono na rysunkach $5 \div 12$ oraz $w$ tablicach IV $\div$ VIII.

\section{Wymiana płyt}
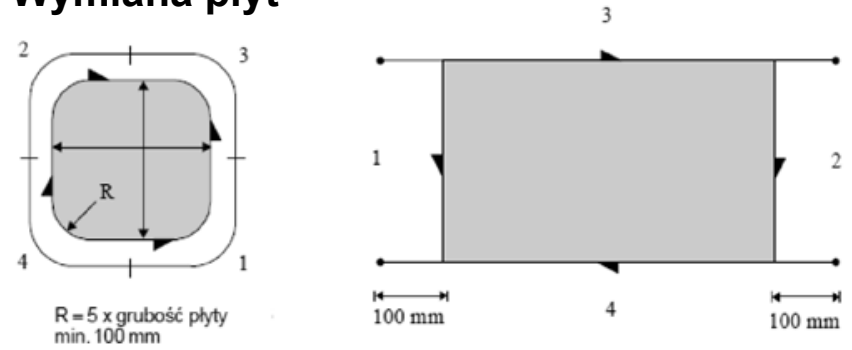

Rys. 5. Kolejność spawania wstawek [1]

Fig. 5. Inserts welding sequence [1]

Tablica IV. Zalecenia przy wymianie płyt. [1]

Table IV. Recommendations for plates replacement [1]

\begin{tabular}{|c|c|c|c|}
\hline Parametr & Standard & $\begin{array}{l}\text { Wartość } \\
\text { graniczna }\end{array}$ & Uwagi \\
\hline $\begin{array}{l}\text { Wymiary } \\
\text { wstawki }\end{array}$ & $\begin{array}{l}\text { Min. } 300 \times 300 \mathrm{~mm} \\
\mathrm{R}=5 \times \text { grubość } \\
\text { blachy. Wstawki } \\
\text { okrągłe: } D_{\min }=200 \\
\mathrm{~mm}\end{array}$ & $\begin{array}{l}\text { Min. } \\
200 \times 200 \\
\mathrm{~mm} \\
\min . \mathrm{R} \\
=100 \mathrm{~mm}\end{array}$ & \\
\hline $\begin{array}{l}\text { Kategoria } \\
\text { materiału }\end{array}$ & \begin{tabular}{|l|} 
Taka sama jak \\
oryginalna lub \\
wyższej kategorii
\end{tabular} & & $\begin{array}{l}\text { Patrz: materiały } \\
\text { w naprawach }\end{array}$ \\
\hline $\begin{array}{l}\text { Przygotowanie } \\
\text { krawędzi do } \\
\text { spawania }\end{array}$ & $\begin{array}{l}\text { Jak dla nowych } \\
\text { konstrukcji }\end{array}$ & & $\begin{array}{l}\text { Przy niezgodno- } \\
\text { ści należy zwięk- } \\
\text { szyć liczbę badań } \\
\text { nieniszczących }\end{array}$ \\
\hline $\begin{array}{l}\text { Kolejność } \\
\text { spawania }\end{array}$ & $\begin{array}{l}\text { Patrz rys. } 5 \text {. Kolej- } \\
\text { ność spawania: } \\
1 \rightarrow 2 \rightarrow 3 \rightarrow 4\end{array}$ & & $\begin{array}{l}\text { Dla wiązań głów- } \\
\text { nych kolejność } 1 \\
\text { i 2, poprzecznie } \\
\text { do kierunku } \\
\text { naprężenia } \\
\text { głównego }\end{array}$ \\
\hline $\begin{array}{l}\text { Przesunięcie } \\
\text { elementów }\end{array}$ & $\begin{array}{l}\text { Jak w przypadku } \\
\text { nowych budów }\end{array}$ & & \\
\hline $\begin{array}{l}\text { Wykończenie } \\
\text { spoin }\end{array}$ & $\begin{array}{l}\text { Przepisy i publika- } \\
\text { cje PRS (p. mate- } \\
\text { riały związane, poz. } \\
{[3] \text { i [4]) }}\end{array}$ & & \\
\hline $\begin{array}{l}\text { Badania } \\
\text { nieniszczące }\end{array}$ & \begin{tabular}{|l|} 
Przepisy i publika- \\
cje PRS (p. mate- \\
riały związane, poz. \\
{$[3]$ i [4]) }
\end{tabular} & & \\
\hline
\end{tabular}




\section{Wymiana elementów wewnętrznych/usztywnień}

Przed spawaniem usunąć spoinę pachwinową na długości wstawki oraz obu końców i dodatkowo na długości min. $d=150 \mathrm{~mm}$

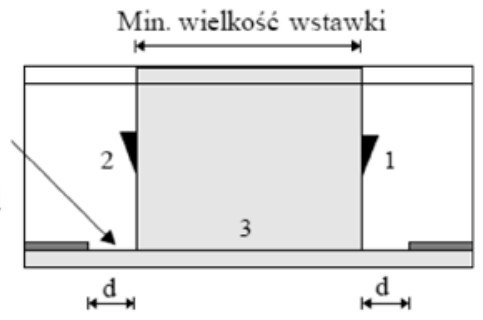

Rys. 6. Kolejność spawania wstawek usztywnień [1]

Fig. 6. Sequence of stiffening insert welding [1]

Tablica V. Zalecenia przy wymianie elementów wewnętrznych [1]

Table V. Recommendations for internal components replacement [1]

\begin{tabular}{|l|l|l|l|}
\hline \multicolumn{1}{|c|}{ Parametr } & \multicolumn{1}{|c|}{ Wartość standardowa } & $\begin{array}{l}\text { Wartość } \\
\text { graniczna }\end{array}$ & Uwagi \\
\hline $\begin{array}{l}\text { Wymiary } \\
\text { wstawki }\end{array}$ & Min. 300 mm & $\begin{array}{l}\text { Min. 200 } \\
\mathrm{mm}\end{array}$ & \\
\hline $\begin{array}{l}\text { Kategoria } \\
\text { materiału }\end{array}$ & $\begin{array}{l}\text { Taka sama jak oryginal- } \\
\text { na lub wyższej kategorii }\end{array}$ & $\begin{array}{l}\text { Patrz materiały } \\
\text { w naprawach }\end{array}$ \\
\hline $\begin{array}{l}\text { Przygotowanie } \\
\text { Krawędzi }\end{array}$ & $\begin{array}{l}\text { Jak dla nowej budowy. } \\
\text { Należy usunąć spoinę } \\
\text { pachwinową między } \\
\text { środnikiem i płytą na } \\
\text { długości wstawki oraz } \\
\text { z obu końców spoiny } \\
\text { min. d = 150 mm }\end{array}$ & & \\
\hline $\begin{array}{l}\text { Kolejność } \\
\text { spawania }\end{array}$ & $\begin{array}{l}\text { Patrz rys. 6: Kolejność } \\
\text { spawania: 1 } \rightarrow \text { 2 } \rightarrow \text { 3 }\end{array}$ & & \\
\hline $\begin{array}{l}\text { Przesunięcie } \\
\text { elementów kon- } \\
\text { strukcyjnych }\end{array}$ & Jak dla nowej budowy & & \\
\hline $\begin{array}{l}\text { Wykończenie } \\
\text { spoiny }\end{array}$ & $\begin{array}{l}\text { Przepisy PRS (p. mate- } \\
\text { riały związane, poz. [3]) }\end{array}$ & & \\
\hline $\begin{array}{l}\text { Badania nie- } \\
\text { niszczące }\end{array}$ & $\begin{array}{l}\text { Przepisy i publikacje } \\
\text { PRs (p. materiały zwią- } \\
\text { zane, poz. [3] i [4]) }\end{array}$ & & \\
\hline
\end{tabular}

\section{Zakończenia nakładek}

Tablica VI. Zalecenia przy zakończeniu nakładek [1]

Table VI. Recommendations for closing of the weld in the cover plate [1]

\begin{tabular}{|l|c|c|l|}
\hline Parametr & $\begin{array}{c}\text { Wartość } \\
\text { standardo- } \\
\text { wa, mm }\end{array}$ & $\begin{array}{c}\text { Wartość } \\
\text { graniczna } \\
\mathrm{mm}\end{array}$ & \multicolumn{1}{|c|}{ Uwagi } \\
\hline $\begin{array}{l}\text { Ścięcie za- } \\
\text { kończenia }\end{array}$ & $\mathrm{l} / \mathrm{b}>3$ & $\begin{array}{l}\text { Należy zwrócić szczególną } \\
\text { uwagę na kształt zakończeń } \\
\text { nakładek w miejscach podat- } \\
\text { nych na zmęczenie }\end{array}$ \\
\hline $\begin{array}{l}\text { Promień } \\
\mathrm{R}\end{array}$ & $0,1 \mathrm{x} \mathrm{b}$ & $\begin{array}{c}\text { Min. 30 } \\
\mathrm{mm}\end{array}$ & $\begin{array}{l}\text { Patrz - ogólne wymagania dla } \\
\text { materiałów }\end{array}$ \\
\hline Materiał & $\begin{array}{l}\text { W zależności od liczby i funk- } \\
\text { cji nakładek. Grubość spoiny } \\
\text { należy zwiększyć o 15\% przy } \\
\text { końcu nakładki }\end{array}$ \\
\hline Spawanie & $\begin{array}{l}\text { Kolejność } \\
\text { spawania } \\
\text { od środka } \\
\text { w kierunku } \\
\text { swobodnych } \\
\text { krawędzi }\end{array}$ & $\begin{array}{l}\text { Patrz rys. 7. Przy spawaniu } \\
\text { odcinków > 1000 mm należy } \\
\text { zastosować spawanie kroko- } \\
\text { wo-wsteczne }\end{array}$ \\
\hline
\end{tabular}

Zakończenie niesymetryczne

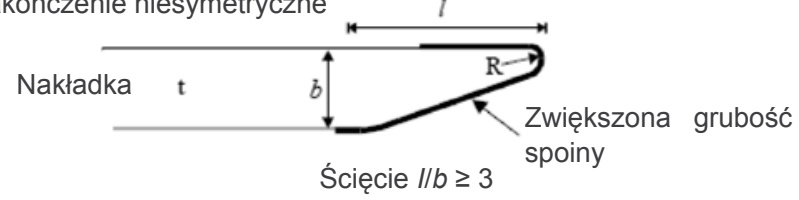

Zakończenie symetryczne

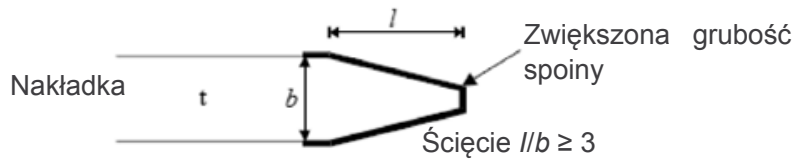

Rys. 7. Zakończenia nakładek [1]

Fig. 7. Closing of the weld in the cover plate [1]

\section{Napawanie wżerów korozyjnych}

Płytkie wżery można pokryć powłoką ochronną lub zaszpachlować. Wżery określa się jako płytkie, jeśli ich głębokość nie przekracza 1/3 wyjściowej grubości blachy.

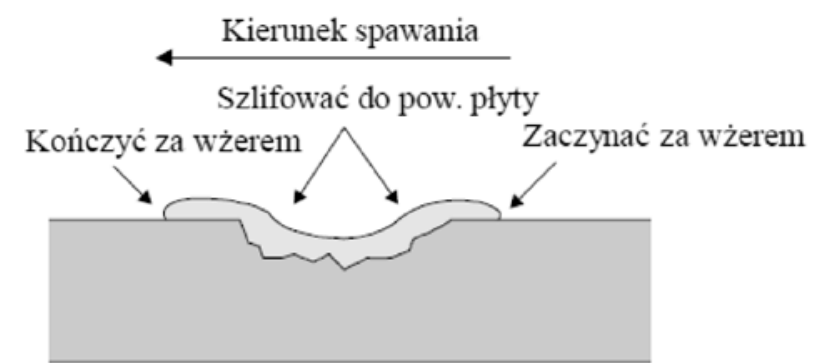

Rys. 8. Napawanie wżerów [1]

Fig. 8. Pit repair [1]

Tablica VII. Zalecenia dotyczące napawania wżerów korozyjnych [1] Table VII. Recommendations for pit repair [1]

\begin{tabular}{|c|c|c|c|}
\hline Parametr & $\begin{array}{c}\text { Wartość } \\
\text { standardowa }\end{array}$ & $\begin{array}{l}\text { Wartość } \\
\text { graniczna }\end{array}$ & Uwagi \\
\hline $\begin{array}{l}\text { Wymiar/ } \\
\text { głębokość }\end{array}$ & $\begin{array}{l}\text { Wżery/rowki nale- } \\
\text { ży zaspawać rów- } \\
\text { no z powierzchnią } \\
\text { wyjściową }\end{array}$ & $\begin{array}{l}\text { W przypadku } \\
\text { zgrupowania } \\
\text { wżerów lub } \\
\text { rowków, albo } \\
\text { gdy pozostała } \\
\text { grubość jest } \\
\text { mniejsza niż } \\
6 \text { mm, należy } \\
\text { wymienić płytę }\end{array}$ & $\begin{array}{l}\text { Patrz także: } \\
\text { przepisy PRS } \\
\text { (materiały zwią- } \\
\text { zane, poz. [3]) }\end{array}$ \\
\hline Czyszczenie & $\begin{array}{l}\text { Należy usunąć gru- } \\
\text { be warstwy rdzy }\end{array}$ & & \\
\hline $\begin{array}{l}\text { Podgrzewanie } \\
\text { wstępne }\end{array}$ & Patrz: tablica III & $\begin{array}{l}\text { Wymagane jest } \\
\text { przy tempera- } \\
\text { turze otoczenia } \\
\text { mniejszej niż } \\
5^{\circ} \mathrm{C}\end{array}$ & $\begin{array}{l}\text { Do usunięcia } \\
\text { wilgoci stoso- } \\
\text { wać zawsze } \\
\text { palnik propano- } \\
\text { wy lub podobny }\end{array}$ \\
\hline $\begin{array}{l}\text { Kolejność } \\
\text { spawania }\end{array}$ & $\begin{array}{l}\text { Zmienić kierunek } \\
\text { przy każdej kolej- } \\
\text { nej warstwie }\end{array}$ & & $\begin{array}{l}\text { Patrz także: } \\
\text { pizepisy PRS } \\
\text { (materiały zwią- } \\
\text { zane, poz. [3]) }\end{array}$ \\
\hline $\begin{array}{l}\text { Wykończenie } \\
\text { spoiny }\end{array}$ & $\begin{array}{l}\text { Przepisy i publi- } \\
\text { kacje PRS (p. ma- } \\
\text { teriały związane, } \\
\text { poz. [3] i [4]) }\end{array}$ & & \\
\hline $\begin{array}{l}\text { Badania } \\
\text { nieniszczące }\end{array}$ & \begin{tabular}{|l|} 
Przepisy i publi- \\
kacje PRS (p. ma- \\
teriały związane, \\
poz. [3] i [4])
\end{tabular} & $\begin{array}{l}\text { Min. 10\% za- } \\
\text { sięgu wżerów }\end{array}$ & \begin{tabular}{|l|} 
Zaleca się \\
badania \\
magnetyczno- \\
proszkowe \\
\end{tabular} \\
\hline
\end{tabular}




\section{Naprawy pęknięć metodą spawania}

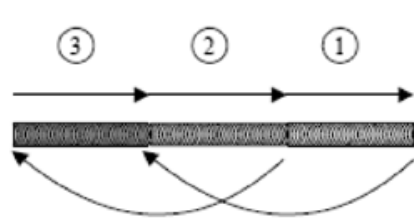

Rys. 9. Technika ściegu krokowo - wstecznego [1]

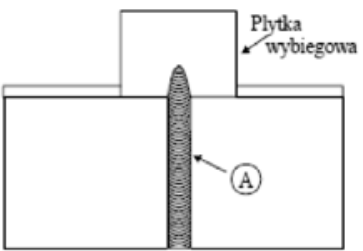

Rys. 10. Obróbka końca pęknięcia [1]

Fig. 9. Back-step sequence techni- Fig. 10. Crack closing treatque [1] ment [1]

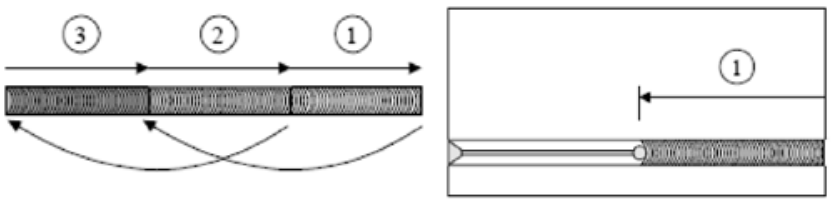

Rys. 11. Kolejność spawania dla pęknięć o długości mniejszej niż $300 \mathrm{~mm}[1]$

Fig. 11. Welding sequence for lower than $300 \mathrm{~mm}$ length cracks [1]

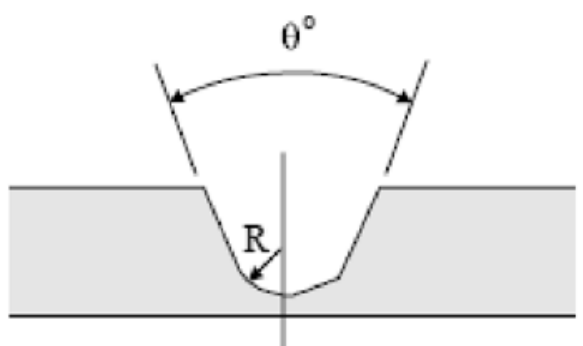

Rys. 12. Przygotowanie (brzeg U po lewej, V po prawej) [1]

Fig. 12. Toe of weld prepartaion ( $U$ in the left, and $V$ in the rigth) [1]

\section{Podsumowanie}

W artykule omówiono wybrane standardy napraw statków na podstawie przepisów krajowych zawartych w wymaganiach Polskiego Rejestru Statków, spójnych z wymaganiami Międzynarodowego Stowarzyszenia Towarzystw Klasyfikacyjnych (IACS). Należy jednak zaznaczyć, że jest to tylko wybrany wycinek standardów, które obowiązują zarówno w budowie, jak i przy naprawach jednostek pływających.

Głównym celem tych standardów jest zapewnienie bezpieczeństwa życia, mienia i środowiska głównie przez tworzenie i weryfikację zgodności technicznych i inżynieryjnych standardów projektowania, budowy i cyklu eksploatacji statków, jednostek morskich i innych obiektów związanych z tą branżą.
Tablica VIII. Zalecenia przy naprawie pęknięć spawaniem Table VIII. Recommendation for crack reparation by welding

\begin{tabular}{|c|c|c|c|}
\hline $\begin{array}{l}\text { Para- } \\
\text { metr }\end{array}$ & $\begin{array}{c}\text { Wartość } \\
\text { standardowa }\end{array}$ & $\begin{array}{c}\text { Wartość } \\
\text { graniczna }\end{array}$ & Uwagi \\
\hline 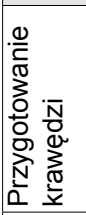 & $\begin{array}{l}\Theta=45 \div 60^{\circ} \\
r=5 \mathrm{~mm}\end{array}$ & & $\begin{array}{l}\text { W przypadku pęknięć } \\
\text { przechodzących } \\
\text { przez całą grubość } \\
\text { płyty naprawa jak dla } \\
\text { nowej budowy. Dla } \\
\text { innych: patrz rys. } 12\end{array}$ \\
\hline 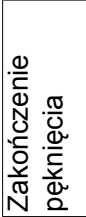 & $\begin{array}{l}\text { Nachylenie zakoń- } \\
\text { czenia } 1: 3\end{array}$ & & $\begin{array}{l}\text { Dla pęknięć kończą- } \\
\text { cych się na krawędzi } \\
\text { koniec spoiny powi- } \\
\text { nien być obrabiany } \\
\text { na płytce wybiegowej } \\
\text { - patrz rys. } 10\end{array}$ \\
\hline 兽 & $\begin{array}{l}\text { Na płycie długości } \\
\text { maks. } 400 \text { mm. } \\
\text { Usunąć pęknięcia } \\
\text { oraz po } 50 \text { mm poza } \\
\text { końcem pęknięcia }\end{array}$ & $\begin{array}{l}\text { Na płycie } \\
\text { maks. } 500 \text { mm. } \\
\text { Pęknięcie linio- } \\
\text { we nierozgałę- } \\
\text { zione }\end{array}$ & \\
\hline 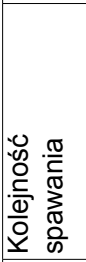 & Patrz rys. 11 & $\begin{array}{l}\text { Dla pęknięć } \\
\text { dłuższych niż } \\
300 \text { mm należy } \\
\text { zastosować } \\
\text { technikę kroko- } \\
\text { wo-wsteczną } \\
\text { (rys. 9) }\end{array}$ & $\begin{array}{l}\text { Należy zawsze } \\
\text { stosować elektrody } \\
\text { niskowodorowe }\end{array}$ \\
\hline 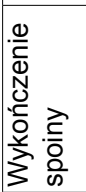 & $\begin{array}{l}\text { Przepisy i publikacje } \\
\text { PRS (p. materiały } \\
\text { związane, poz. [3] } \\
\text { i [4]) }\end{array}$ & & \\
\hline 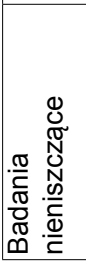 & $\begin{array}{l}\text { Przepisy i publikacje } \\
\text { PRS (p. materiały } \\
\text { związane, } \\
\text { poz. [3] i [4]) }\end{array}$ & $\begin{array}{l}\text { Badania } \\
\text { metodą ma- } \\
\text { gnetyczną lub } \\
\text { penetracyjną } \\
100 \% \text { rowka }\end{array}$ & $\begin{array}{l}\text { Badanie } 100 \% \\
\text { pęknięć powierzch- } \\
\text { niowych - badanie } \\
\text { metodą ultradźwię- } \\
\text { kową lub radiolo- } \\
\text { giczną dla połączeń } \\
\text { doczołowych }\end{array}$ \\
\hline
\end{tabular}

\section{Literatura}

[1] Publikacja $\mathrm{nr}$ 16/l. Standardy budowy i naprawy statków. Gdańsk 2011.

[2] IACS - Bulk Carriers - Guidelines for Surveys, Assessment and Repair of Hull Structure.

[3] Przepisy klasyfikacji i budowy statków morskich. Część IX Materiały i spawanie. Gdańsk 2011.

[4] Publikacja nr 36/P. Przeglądy kadłuba zbiornikowców olejowych. Gdańsk 2010.

[5] Chmielowski A.: Zabezpieczenie przeciwkorozyjne konstrukcji stalowych - powłoki malarskie. Wrocław 1977.

[6] Doerffer J.: Technologia remontów statków. Wydawnictwo Morskie. Gdańsk 1974

[7] http://pl.wikipedia.org/wiki/Towarzystwo_klasyfikacyjne. 